\title{
MODIS-based vegetation index has sufficient sensitivity to indicate stand-level intra-seasonal climatic stress in oak and beech forests
}

Article

Accepted Version

Hlásny, T., Barka, I., Sitková, Z., Konôpka, M., Bucha, T. and Lukáč, M. (2015) MODIS-based vegetation index has sufficient sensitivity to indicate stand-level intra-seasonal climatic stress in oak and beech forests. Annals of Forest Science, 72 (1). pp. 109-125. ISSN 1286-4560 doi: https://doi.org/10.1007/s13595014-0404-2 Available at https://centaur.reading.ac.uk/37046/

It is advisable to refer to the publisher's version if you intend to cite from the work. See Guidance on citing.

To link to this article DOI: http://dx.doi.org/10.1007/s13595-014-0404-2

Publisher: Springer

All outputs in CentAUR are protected by Intellectual Property Rights law, including copyright law. Copyright and IPR is retained by the creators or other copyright holders. Terms and conditions for use of this material are defined in the End User Agreement. 


\section{CentAUR}

Central Archive at the University of Reading

Reading's research outputs online 
2 indicate stand-level intra-seasonal climatic stress in oak and beech

\title{
forests
}

\author{
${ }^{1,2}$ Tomáš Hlásny, ${ }^{1,2}$ Ivan Barka, ${ }^{1}$ Zuzana Sitková, ${ }^{1}$ Milan Konôpka, ${ }^{1}$ Tomáš \\ Bucha, ${ }^{3}$ Martin Lukáč \\ ${ }^{1}$ National Forest Centre - Forest Research Institute Zvolen, T. G. Masaryka 22, \\ 96092 Zvolen, Slovak Republic \\ ${ }^{2}$ Czech University of Life Sciences Prague, Faculty of Forestry and Wood \\ Sciences, Kamýcká 129, 16521 Prague 6, Czech Republic \\ ${ }^{3}$ School of Agriculture, Policy and Development, University of Reading, RG6 \\ 6AR, United Kingdom
}

17 Abstract

18 Context: Variation in photosynthetic activity of trees induced by climatic stress can be

19 effectively evaluated using remote sensing data. Although adverse effects of climate on

20 temperate forests have been subjected to increased scrutiny, the suitability of remote

21 sensing imagery for identification of drought stress in such forests has not been explored

22 fully.

23 Aim: To evaluate the sensitivity of MODIS-based vegetation index to heat and drought

24 stress in temperate forests, and explore the differences in stress response of oaks and

25 beech.

26 Methods: We identified 8 oak and 13 beech pure and mature stands, each covering

27 between 4 and 13 MODIS pixels. For each pixel, we extracted a time series of MODIS

28 NDVI from 2000 to 2010 . We identified all sequences of continuous unseasonal NDVI

29 decline to be used as the response variable indicative of environmental stress. Neural 
30 Networks-based regression modelling was then applied to identify the climatic variables

31 that best explain observed NDVI declines.

32 Results: Tested variables explained $84-97 \%$ of the variation in NDVI, whilst air

33 temperature-related climate extremes were found to be the most influential. Beech

34 showed a linear response to the most influential climatic predictors, while oak responded

35 in a unimodal pattern suggesting a better coping mechanism.

36 Conclusions: MODIS NDVI has proved sufficiently sensitive as a stand-level indicator

37 of climatic stress acting upon temperate broadleaf forests, leading to its potential use in

38 predicting drought stress from meteorological observations and improving

39 parameterisation of forest stress indices.

40 Key words: drought stress, heat stress, NDVI, regression modelling, temperate forest,

41 neural networks

42

43 Executive summary

44 This study explores the suitability of MODIS satellite imagery for the detection of intra-

45 seasonal heat and drought stress in temperate forests. It is clear that this data can provide

46 valuable information complementary to forest stand-based ecophysiological research and

47 allows for the quantification of inter-specific differences in stress response. 
49 The effect of extreme climate events on terrestrial ecosystems is being increasingly

50 recognized as one of the first signs of impending climate change (Allen et al. 2010;

51 Leuzinger et al. 2005). Survival of woody species within their present range is likely to

52 be constrained by water availability, prolonged drought during vegetation season may

53 induce episodes of large-scale tree decline (Allen et al. 2010; McDowel et al. 2011).

54 Drought induced tree mortality has mainly been observed in the Mediterranean region,

55 affecting a range of species (for an overview see Allen et al. 2010). Further north, lack of

56 water has been identified chiefly as a predisposing factor for biotic stressors, for example

57 drought periods repeatedly triggering large-scale pest outbreaks (Rouault at al. 2006). In

58 temperate forests, repeated episodes of drought usually cause a decrease in leaf area index

59 (Le Dantec et al. 2000), often resulting in a decline in forest productivity (Glenn et al.

60 2008, Hlásny et al. 2011a). However, some recent observations such as drought induced

61 mass beech mortality (Lakatos and Molnár 2010) or drought-triggered pest outbreaks

62 (Mátyás et al. 2010) indicate the importance of drought as an emerging primary mortality

63 agent in temperate Europe. This link is underlined by the presence of drought sensitive

64 xeric limit of several temperate tree species, as well as by projections indicating drought

65 induced retreat of some species (Czúcz et al. 2011, Hlásny et al. 2011a). European beech

66 (Fagus sylvatica) and several oaks (Quercus sp.) overlap to a certain extent and together

67 they constitute some of the ecologically and economically most important species. Oaks

68 are favoured by a relatively warm and dry climates (Czúcz et al. 2011; Epron and Dreyer

69 1993), while beech has been identified as sensitive to drought and potentially vulnerable

70 to climate change (Geßler et al. 2007; Mátyás et al. 2010; Leuzinger et al. 2005). Since

71 climate change may force a replacement of beech by oaks in some localities, the

72 competitiveness and stress tolerance of beech and various oak species is being 
increasingly recognized as central to future-proofing broadleaf temperate forests

74 (Leuschner et al. 2001; Raftoyannis and Radoglou 2002; Scharnweber et al. 2011).

75 Traditionally, the frequency and severity of drought has been evaluated by drought

76 indices calculated from meteorological observations (Vicente-Serrano et al. 2012). Since

77 forests are sparsely covered by meteorological stations (Caccamo et al. 2011), this

78 approach does not allow for a reliable drought assessment of a large area or in a varied

79 landscape. Variations in photosynthetic activity induced by climatic or other stress can,

80 however, be effectively evaluated using remote sensing data (Glenn et al. 2008; Lobo et

81 al. 2010). Fine spectral resolution in the water sensitive part of the electromagnetic

82 spectrum makes MODIS sensor (Moderate Resolution Imaging Spectroradiometer,

83 NASA) outstandingly suitable for drought monitoring (Ceccato et al. 2001). During the

84 MODIS mission (from 2000 onwards), the instrument has generated large amounts of

85 data used for monitoring of drought and water availability at global to regional scales. To

86 date, however, few studies have explored the utility of MODIS-type data to monitor

87 drought in forested areas (Caccamo et al. 2011; Vacchiano et al. 2012; Wang et al. 2009),

88 with Central Europe not covered at all. Spectral reflectance data are usually compressed

89 into vegetation indices. One such index, the widely used Normalised Difference

90 Vegetation Index (NDVI), exploits the variation in the absorption of photosynthetically

91 active radiation by living plant foliage (Myneni and Williams 1994). Since photosynthetic

92 activity is limited by resource availability, NDVI has also been used to investigate the

93 incidence and severity of drought (Caccamo et al. 2011; Ji and Peters 2003).

94 In the present study, we investigate the usability of MODIS-NDVI as an indicator of the

95 severity of vegetation stress resulting from a potential water deficit and excessive

96 temperatures in mature beech and oak stands in Central Europe. We hypothesize that (i)

97 specific stress episodes can be identified in time series of MODIS-NDVI localised to 
forest stands, and (ii) these patterns are linked to specific intensity and duration of

99 rainless and heat periods. We perform a regression modelling analysis to assess the

100 usefulness of MODIS imagery for investigations of intra-seasonal variation of forest

101 vigour and to identify environmental variables which best predict the stress response of

102 beech and oak stands.

103

104

1. Materials and methods

$105 \quad 2.1$ Study region and experimental plots

106 The research focuses on the territory of Slovakia (Central Europe) where a number of

107 forest plots distributed across the whole country were identified. Forest management

108 plans and other databases archived by the National Forest Centre, Slovakia, were used to

109 localise experimental plots using criteria listed in Table 1.

110 Table 1

111 The purpose of stand selection was to create a database of mature and homogenous oak

112 and beech stands seamlessly covering groups of MODIS pixels $(250 \times 250 \mathrm{~m}$, see

113 Appendix A). Oak stands contained mixtures of Sessile oak (Quercus petrea),

114 Pedunculate oak (Quercus robur) and Pubescent oak (Quercus pubescens). Only single-

115 layer stands with closed canopy were considered for this study. Each selected stand was

116 composed of at least $99 \%$ of the target species. This threshold was set arbitrarily high to

117 allow for a reasonable confidence in inter-specific comparison. To reduce the variability

118 of potential stress responses, we used digital forest soil maps to exclude forest stands on

119 soils with extremely low or high water holding capacity. As a result, the only soil type

120 under the final selection of stands is sandy loam or loam of medium depth (ca. up to 120

$121 \mathrm{~cm}$ in oak plots) or medium-to-high depth (ca. up to $200 \mathrm{~cm}$ in beech plots). 
123 plots covered by 55 MODIS pixels met the selection criteria (Fig. 1, Table 2).

$124 \quad$ Fig. 1

125 Table 2

126

127

\subsection{Time series of MODIS-NDVI}

128 NDVI is an approximately linear estimate of the fraction of photosynthetically active radiation (PAR) intercepted by photosynthesizing tissue of vegetation, provided that certain constraints on background, solar and view angles, and atmospheric transparency are fulfilled (Myneni and Williams 1994). NDVI is formulated as:

where $\rho$ NIR and $\rho$ Red are reflectance values of near infrared and red radiation.

Hence, NDVI theoretically takes on values between -1 and 1 , with values approaching 1

137 indicating high density of green leaves with good photosynthesizing performance.

138 For the purpose of this study, NDVI images with spatial resolution $250 \times 250 \mathrm{~m}$ covering the period 2000-2010 were derived from MODIS product MOD09GQ (Source: NASA LP DAAC). Despite potentially adverse effect of anisotropical reflectance of vegetation on the use of daily MODIS data (e.g. Shuai et al. 2013), we made preference for this product over 16-day products with $500 \mathrm{~m}$ resolution which are free of this potentioal

143 source of error. Since we strive to focus on the immediate vegetation dynamics at daily

144 scale in the varied landscape of Central Europe, the spatial resolution of used imagery can

145 critically limit the usability of such imagery. Indeed, Franch et al. (2013) suggested that 
errors due to the Lambertian assumption in daily MODIS data are likely to be negligible

147 in case of NDVI values.

148 Since clouds and atmospheric aerosols can introduce substantial noise in MODIS NDVI

149 data (Wang et al. 2003, Hmimina et al. 2013), a two-step quality control has been applied

150 to remove observations contaminated by atmospheric or other interference. First,

151 MOD09GA (500x500) product was used to exclude images taken under high sensor

152 zenith angles, and pixels contaminated by clouds and aerosols. Despite lower resolution,

153 MOD09GA is better suited for this step than MOD09GQ with $250 \mathrm{~m}$ resolution, since the

154 latter product does not contain information on pixel contamination by aerosols.

155 Moreover, MOD09GA contains information detected in all spectral bands of MODIS

156 (range 459-2,155 nm), supporting its superior performance in the detection of

157 contaminated pixels. Indeed, cloud masks based on this product have been shown to

158 slightly overestimate real clouding (Kotarba et al. 2009). Despite a very conservative first

159 step, a portion of noise can remain in the data even after the quality assurance image was

160 applied (Hmimina et al. 2013, Wang et al. 2003). Therefore, we applied a follow-up

161 manual quality control procedure aimed at removal of NDVI values which were

162 inconsistent with the expected annual cycle of vegetation greenness (Bruce et al. 2006).

163

$164 \quad 2.3$ Climate data and definition of drought and heat periods

165 Daily meteorological data collected at 46 meteorological stations in the vicinity of

166 experimental plots (Fig. 1) (Source: Slovak Hydrometeorological Institute) were used for

167 the identification of rainless periods and periods during which daily mean or maximum

168 air temperature exceeded selected thresholds (Table 4). Meteorological stations indicative

169 of conditions specific to each experimental plot were selected from the national network

170 of stations using the following criteria: horizontal and vertical distance from selected 
stands (Table 1); landscape orography and climatic variability of broader surroundings.

172 The latter two criteria were included to prevent interpolation over mountain ridges and

173 across climatically different regions.

174 Daily average, minimum and maximum air temperature and daily precipitation data were

175 interpolated to the centre position of each experimental plot. A rainless period was

176 defined as a sequence of days during which no more than $5 \mathrm{~mm}$ of precipitation was

177 recorded per day. This value represents precipitation with low probability of reaching the

178 roots due to interception loss in the canopy (van de Salm et al. 2007), as well as

179 evaporation from the ground. Since no information on actual soil or leaf water content is

180 available at the desired scale and terrain cover, we use the duration of rainless periods as

181 a proxy for drought. For the sake of simplicity, we use term "drought stress" for NDVI

182 responses induced by prolonged rainless periods, being aware of the limitations of such

183 interpretation.

184 A heat period was defined as sequence of days with mean or maximum air temperature

185 exceeding arbitrarily set thresholds (Table 4).

1862.4 Identification of stress episodes in MODIS-NDVI time series 2000-2010

187 Stress episodes were defined as continuous sequences of declining NDVI values observed

188 during the period of full foliage. Each NDVI value pertaining to a stress episode was

189 expressed in terms of actual decline in NDVI relative to the overall permissible decline

190 observed in each MODIS pixel (local amplitude) and calculated according to the

191 following formula:

192

193

$\mathrm{NDVI}_{\text {decline }}=100-\left(\left(\mathrm{NDVI}_{\max }-\mathrm{NDVI}_{\text {stress }}\right) /\left(\mathrm{NDVI}_{\max }-\mathrm{NDVI}_{\min }\right) \times 100\right)$

Eq. 2

194 
where $\mathrm{NDVI}_{\max }$ represents the NDVI of unstressed vegetation and is calculated as the mean of 2-4 NDVI observations immediately preceding a stress episode, $\mathrm{NDVI}_{\text {stress }}$ is a value in a sequence of declining NDVI values, and $\mathrm{NDVI}_{\min }$ is the lowest value of annual NDVI amplitude, correspondent with a period without foliage. $\mathrm{NDVI}_{\min }$ was constant during the investigated 10 year period, reaching 0.52 for beech and 0.44 for oak; these values were found to be uniform across all investigated plots and in all years. The difference between $\mathrm{NDVI}_{\max }$ and $\mathrm{NDVI}_{\min }$ defines the local amplitude for each pixel (Fig. 2). Introducing local amplitudes allows for comparability of NDVI declines in spite of inter-annual and inter-pixel variability in $\mathrm{NDVI}_{\max }$. In addition, $\mathrm{NDVI}_{\max }$ of unstressed vegetation constantly declines from spring to late summer, i.e. from ca. 1.0 to 0.9 (Soudani et al. 2012); hence the need for data standardisation. As a consequence, the local amplitude of NDVI is smaller in beech ( 0.52 to local maximum) than in oak ( 0.44 to local maximum).

Only stress episodes consisting of at least 3 sequentially declining values observed in at least two MODIS pixels from each experimental plot were considered. Also, the magnitude of each decline was set to exceed 5\% of local NDVI amplitude. Stress episodes were extracted manually for each pixel during the vegetative season over the entire 10-year period. The length and timing of periods of full foliage differed between years and pixels, as indicated by the seasonal course of NDVI values. The fact that only the period of full foliage was considered, together with the strict stand selection criteria described earlier, implies that forest understory and herbaceous layer should not affect the evaluated spectral response.

\section{Fig. 2}


221 Three types of interaction between stress episodes and climatic extremes may occur in 222 this type of studies; (i) climate extremes (rainless and/or heat periods) correspond with 223 incidence of NDVI declines (True Responses, TRs), (ii) NDVI declines occur in periods

224 when no heat and rainless period has occurred (False Responses, FRs), (iii) no NDVI decline is apparent during heat and rainless periods (False Triggers, FTs). An inclusion of

226 FRs and FTs in the regression analysis is not possible because either the dependent or explanatory variable(s) would be missing. However, a very high occurrence of FRs and

228 FTs in the dataset may hinder proper interpretation of results of regression modelling. To

229 investigate this possibility, we quantified the frequency of FRs and FTs.

230 Maximum NDVI $_{\text {decline }}$ value observed in each stress episode (Eq. 2, Fig. 2) is used as the 231 dependent variable and regressed against the list of explanatory variables given in Table

232 4. Regression modelling was run independently for the two species to facilitate an 233 evaluation of inter-specific differences in stress response. First, bootstrap sampling was 234 applied repeatedly to randomly split input data into training, testing, and validation sets in 235 the ratio of 70:15:15. Then, Neural Network-based modelling was used, following the 236 workflow described by Hlásny et al. (2011b). In total, 2,000 Neural Networks with 237 varying architecture were trained for each species; the training represents an iterative 238 fitting of a neural network-based model into parameterisation data while controlled by 239 testing and validation samples. Correlation coefficients between $\mathrm{NDVI}_{\text {decline }}$ values 240 predicted by trained Neural Networks and observations allocated to testing and validation 241 sets were calculated to assess the predictive power of trained networks. Subsequently, an 242 ensemble of 15 best-performing networks (i.e. those reaching the highest correlation coefficients between observed and predicted $\mathrm{NDVI}_{\text {decline }}$ values) out of the initial set of 
2442,000 trained networks was used to identify the most influential predictors and to rank

245 them using the sensitivity analysis procedure.

246 The sensitivity analysis used in this study iteratively discards an input variable at a time

247 and assesses overall network error. A measure of sensitivity then is the ratio of the error

248 produced by a Neural Network with a missing variable relative to the error of a Network

249 with the full set of input variables. The more sensitive the network is to the inclusion of a

250 particular input, the greater the measured deterioration of prediction and therefore the

251 greater the error ratio (1 represents a neutral relationship).

252 Since each of the 15 retained networks generates one set of sensitivity scores (SS), the

253 stability of regression models in terms of prediction consistency can be tested. We used

254 the Principal Component Analysis (PCA) to evaluate the inter-model consistency of

255 sensitivity scores on the basis of correlation of all 15 SS sets with the Principal

256 Component 1 (PC1); high correlations of all SS with PC1 indicate consistent signal

257 produced by all models (Hlásny et al. 2011b). All statistical analyses were performed in

258 Statistica Neural Networks v.10 (StatSoft Inc., 2004).

\section{Results}

261

\subsection{Stress episodes}

262 The mean length of observed continuous declines in NDVI was 10.6 days in beech and

26312.5 in oak stands $(\mathrm{P}=0.023)$, while the longest observed period of continuous NDVI

264 decline was 27 days in beech and 24 days in oak (see Appendix B for an example).

265 The most severe declines of NDVI during a stress episode (NDVI decline $_{\text {e }}$ reached $25-30 \%$

266 of the local NDVI amplitude in beech and $40-45 \%$ in oak stands. The variability of

$267 \mathrm{NDVI}_{\text {decline }}$ was larger in oak stands; standard deviation of declines reached $57 \%$ of mean

268 in beech and 70\% in oak (Table 3). We found that each NDVI $_{\text {decline }}$ episode was

269 associated with a single rainless period, while several heat periods from one to several 
days long occurred within its duration. None of the heat periods identified by the

271 thresholds specified for this research (Table 4) was sufficiently long to induce an

272 observable decline in NDVI values. Stress episodes always ended at first precipitation

273 event which cancelled the respective rainless period. NDVI recovered to its local

274 maximum shortly after and no irreversible changes were observed.

275 Table 3

276 As a technical verification study, we explored spectral responses of foliage to drought in the red $(620-670 \mathrm{~nm})$ and near infrared band (840-876 nm, Appendix C). The same bands

278 were used to calculate NDVI values in the main objective of this manuscript (Eq. 1).

279 Bench-top NDVI declines are mainly related to an increased reflectance in the red band,

280 which is indicative of reduced photosynthetic performance of vegetation (i.e. lesser

281 absorption and higher reflectance of photosyntheticaly active radiation,Reflectance in the

282 near infrared band was found to increase as well, although the pattern of increase was not

283 as clear as that of the red band. We observed more than threefold increase in the

284 reflectance in the red band at the end of stress periods lasting from 10 to 20 days, as

285 compared to unstressed vegetation. Increased absorption in the near infrared band, which

286 could be indicative of drought induced changes in leave cell walls, was not observed in

287 the current investigation.

\subsection{Regression modelling}

290 Correlations between predicted and observed values, calculated as the mean of 15 best

291 performing networks for each tree species (Table 5) show only small inter-network

292 variability and were very similar between training, testing and validation sets. The range

293 of correlation coefficients between 0.84-0.97 implies stable and well performing 
regression models. The coefficients suggest that explanatory variables utilised in this

295 analysis explain a significant portion of the variability of identified stress episodes.

296 Table 5

297 Sensitivity scores (SS) produced by the 15 best-performing regression models were found

298 to be highly consistent among the models. PC1 explained $81 \%$ of the total variability of

299 SS in beech and 76\% in oaks and SS of no model differed significantly from the main

300 pattern represented by PC1. Differences in mean sensitivity scores indicated variation in

301 the predictive power of explanatory variables between the two tree species, suggesting

302 diverging physiological capacity to respond to heat and drought stress (Table 6). The

303 largest difference was observed for GDD, which was the most influential predictor in

304 beech $(\mathrm{SS}=4.62)$, while occupying only the $5^{\text {th }}$ position in oak $(\mathrm{SS}=1.61)$. The number of

305 days with average air temperature above $24^{\circ} \mathrm{C}$ was the most influential variable in oak

306 (SS=5.60), whilst in beech the number of days with maximum air temperature above 29

307 and $20^{\circ} \mathrm{C}$ were the most influential of temperature related predictors ( $\mathrm{SS}=4.00$ and 3.90).

308 The duration of rainless periods was not found to affect the stress response significantly

309 ( $15^{\text {th }}$ order with $\mathrm{SS}=1.27$ in beech, and $12^{\text {th }}$ order with $\mathrm{SS}=1.32$ in oak $)$, and its

310 importance was greatly subdued by heat-related variables. Non-climatic variables such as

311 elevation and stand age did not affect declines of NDVI. In oaks, mean SS of the most

312 influential variables (N-Tavg $\left.>24^{\circ} \mathrm{C}, \mathrm{N}-\mathrm{Tmax}>32^{\circ} \mathrm{C}, \mathrm{N}-\mathrm{Tmax}>29^{\circ} \mathrm{C}\right)$ differed

313 significantly from each other, as well as from all lower-rank variables ( $\alpha=0.05$, Tab. 6$)$. In

314 beech, the decrease in SS from the first to the last-ranked variable was not so apparent,

315 however the mean SS of the group of most influential variables was significantly

316 different from the lower-rank variables.

317 Table 6

318 
321 In order to understand the phenological and physiological implications of the most

322 influential explanatory variables, we further analysed dominant relationships. Diverging

323 response to the most influential climatic variables was found in oak, which has shown

324 highest NDVI declines at short to medium duration of unfavourable climate, while longer

325 duration stress events were accompanied by less severe NDVI declines. The largest

326 decreases of NDVI were induced by 1-2 hot days accumulated during stress episodes

327 with average daily air temperature above $24^{\circ} \mathrm{C}$ (the most influential variable, SS=5.60),

328 though the variability of responses was high (Fig. 3a). Unimodal response was observed

329 at $\mathrm{N}-\mathrm{Tmax}>29^{\circ} \mathrm{C}(\mathrm{SS}=2.51)$ with maximum NDVI declines at around 2-4 days (Fig. 3b).

330 Linearly decreasing response was observed at $\mathrm{N}-\mathrm{Tmax}>32^{\circ} \mathrm{C}(\mathrm{SS}=3.18)$ (Fig. 3c), with

331 extreme variability at 0 days (i.e. at NDVI declines with no observation of temperature

332 above $32^{\circ} \mathrm{C}$ ); the reason for this is the low number of stress episodes during which days

333 with air temperature exceeded the threshold of $32^{\circ} \mathrm{C}$.

334 Fig. 3

335 In contrast to oak, increasing the severity or the duration of heat stress in beech increased

336 the magnitudes of NDVI declines in linear fashion. The main univariate relationships

337 between the most influential climatic variables and the stress response of beech are

338 presented in Fig. 4.

339 Fig. 4

340 The only explanatory variable to which we observed a unimodal response in both species

341 was GDD (Fig. 3e, 4e). Interestingly, the GDD value denoting the highest NDVI

342 sensitivity was between 900-1,000 in both beech and oak. Observed length of a drought

343 period was not influential in either species ( $\mathrm{SS}=1.27$ in beech and $\mathrm{SS}=1.32$ in oak), it is

344 however functionally associated to all observed stress episodes. A drought ends at a 
precipitation event and NDVI recovers to its local and seasonal maximum shortly after.

346 Considering it on a univariate basis indicates a linear relationship between the length of

347 drought and corresponding magnitude of NDVI declines in beech, but a quadratic

348 relationship in oak (Fig. 3d, 4d).

349

350

\subsection{Incidence of False Responses and False Triggers}

351

Relationships between frequencies of rainless periods longer than 4 days which were characterised by at least 3 non-declining NDVI observations and rainless periods inducing a stress response were studied. The 4-day criterion was chosen to avoid affecting the analysis by a large number (in the order of thousands) of rainless periods of short duration which are largely irrelevant for tree stress assessment. In beech, a remarkably strong prevalence of rainless periods up to 20 days long with non-declining NDVI values was identified (Fig. 5). In rainless periods longer than 20 days, however, a relatively equal frequency of FTs and TR was observed. In oaks, the frequency of FTs is substantially higher than the frequency of rainless periods inducing stress response for all durations of rainless periods.

Fig. 5

3. Discussion

\subsection{Ecophysiological inference and applicability}

365 Currently, even small changes in precipitation regime are thought to have a considerable 366 impact on beech, raising the possibility of co-occurring species such as oak gaining a 367 competitive advantage under projected climatic changes (Scharnweber et al. 2011).

368 Oaks appear to possess the capacity to better tolerate drought, an array of efficient protection mechanisms against permanent high irradiance damage under drought stress 
372 As indicated in our analysis, drought approximated by the duration of rainless periods

373 induced a reduction in photosynthetic activity indicated by NDVI in both species.

374 Observed climatic stress did not result in irreversible tree decline and mortality in either

375 species, such an event would have been evidenced by a discontinuity in the investigated

376 NDVI time series. Generally, drought-induced damage may lead to organ dysfunction,

377 but it only seldom results in direct and immediate induction of tree decline and death

378 (Bréda et al. 2006). Hence, continuous decline of NDVI values in years following

379 extreme droughts is more likely to occur than intra-seasonal abrupt change not followed

380 by a recovery, as reported in France when a substantial increase in tree mortality occurred

381 in years after the 2003 heat wave (Renaud et al. 2006).

382 In this study, the variability of maximum NDVI declines was higher in oak than in beech,

383 possibly related to differences in the plasticity of response, but also the presence of

384 several oak species in oak experimental plots (Q. petrea, Q. robur, $Q$. pubescens).

385 Differential response of oak species to drought has been reported by Epron and Dreyer

386 (1993) or Raftoyannis and Radoglou (2002). Mean and maximum observed NDVI

387 declines were greater in oak than in beech, even though the photosynthetic rate of beech

388 was found to significantly decrease at low water potentials, while oaks maintained high

389 rates of photosynthesis even under very low leaf water potentials and high air

390 temperatures (Raftoyannis and Radoglou 2002).

391 Our investigation revealed that NDVI response to climatic stress was related to an 392 increase in the reflectance in both red and near infrared band. While the increase in the 393 red band can be related to the reduced rate of absorption of the photosyntheticaly active 394 radiation (Glenn et al. 2008), increased reflectance in the near infrared band currently 395 lacks an acceptable interpretation. This spectral range is mainly sensitive to internal leaf 
structure and leaf dry matter content (Ceccato et al. 2001), and is normally expected to 397 increase with vegetation curing (drying and dying; Cheney and Sullivan 1997). However, 398 in our verification experiment (Appendix C), the increase in the reflectance in the near 399 infrared band was minor compared to that of the red band. Caccamo et al. (2011) stated 400 that the evaluation of performance of MODIS-derived spectral indices in the visible, near 401 infrared and short wave infrared bands has only been conducted in agricultural areas but 402 not for high biomass ecosystems; therefore further research is needed to understand such 403 responses thoroughly.

404 The sensitivity analysis indicated that the two species respond to slightly different drivers 405 of environmental stress. GDD, and mean and maximum daily temperatures above 20 and $40624^{\circ} \mathrm{C}$ respectively, concurrent to rainless periods, were the most important variables in 407 driving the observed declines in NDVI in beech stands. In temperate climate the 408 probability of physiological drought is closely correlated with the period of greatest 409 photosynthetic activity, the fact that GDD is the best predictor of NDVI decline in beech 410 suggests a strong link to phenology with diminished potential for adaptation to the 411 environmental stress driver. The strong link of observed stress episodes to GDD may thus 412 imply that beech - in contrast to oak - may lack sufficient phenotypic plasticity to 413 mitigate the effects of expected climate change. In this regard, Nahm et al. (2007) found 414 uniform drought response of beech stands distributed from southern France to central 415 Germany. Mátyás et al. (2010) suggest that phenotypic plasticity of beech populations is 416 considerable, but ceases to buffer stress near the xeric limit of the species. On the other 417 hand, Weber et al. (2013) suggested that beech near their dry distribution limit are 418 adapted to extreme conditions already and should be less affected physiologically, while 419 changes in the growth patterns of beech under mesic conditions have to be expected. 420 Strong effect of GDD on beech stress response may be related to the functionality of 421 antioxidant systems (Rennenberg et al. 2006). Polle et al. (2001) claim that under 
extended periods of drought and elevated air temperatures, mature beech leaves which

423 were normally highly stress-tolerant became very susceptible to oxidative stress, what

424 may be the case of our observations.

425 The relationship between the length of drought periods and NDVI declines in our beech

426 stands is linear, supporting the assertion of Leuzinger et al. (2005) that beech does not

427 possess a coping mechanism which would limit the effect of cumulative damage. Nahm

428 et al. (2007), however, argue in their investigation of beech performance after extreme

429 heat and drought in summer 2003 that beech possess effective regulation mechanisms

430 when facing even severe drought and heat periods. This issue does not appear to be

431 settled yet, other authors found adverse effects of heat and drought on beech

432 physiological performance (e.g. Epron and Dreyer 1993; Raftoyannis and Radoglou

433 2002; Wamelink et al. 2009), including effect on tree growth (Scharnweber et al. 2011).

434 In contrast to beech, the magnitude of NDVI declines in oak stands was found to be

435 sensitive primarily to increased temperature in a unimodal pattern. Our data show that

436 increasing the number of days which exceed a temperature threshold and/or prolonging

437 the rainless period does not have a linear effect on the decrease of NDVI. Species which

438 evolved to colonise drier environments tend to cope better with episodes of drought

439 accompanied by high temperatures than mesic-adapted species (Sack,

440 2004; Engelbrecht et al., 2005). A crucial difference in the physiology of beech and oak

441 might explain the reduction of photosynthetic activity observed in this study in response

442 to drought (Figure 3). Beech typically displays isohydric behaviour of progressively

443 limiting stomatal conductance to maintain water potential (Cochard 1999), which is likely

444 reflected in linearly decreasing rate of photosynthesis. Oaks, on the other hand, have been

445 shown to use their extensive root systems to support anisohydric behaviour of tolerating

446 decreasing water potential (Thomsen 2013). Stomata closure would initially limit 
transpiration as water availability decreases at the onset of drought, but do not close completely to maintain limited carbon fixation as the drought continues.

\subsection{Methodological comments and limitations}

451 Daily observations of MODIS sensor with spatial resolution $250 \times 250$ meters can provide 452 highly valuable data in many fields of vegetation science. There are, however, numerous 453 obstacles which need to be overcome to gain reasonable confidence in the inferences 454 based on such data. The substantial noise present in the data requires a comprehensive 455 quality control to facilitate their use (Wang et al. 2003, Hmimina et al. 2013). The 456 anisotropy in the spectral reflectance of vegetation has also been recognized as factor 457 potentially limiting the use of daily NDVI data, and corrections to reduce this effect have 458 been proposed (e.g. Shuai et al. 2013). While quality assurance metadata and other QA 459 procedures can be used to substantially reduce the noise in daily data, effect of anisotropical reflectance persists. The use of 16-day MODIS products is suggested to avoid this effect, this product however does not offer the potential to study immediate vegetation responses to climatic and other stresses. The fact that we accepted an assumption of forest vegetation representing a Lambertian surface (i.e. with isotropic reflectance) should not significantly affect our analysis. Franch et al. (2013) found that while relative errors due to the Lambertian assumption in daily MODIS data are 3-12\% in visible and $0.7-5 \%$ in infrared spectrum, they reach only $1 \%$ in NDVI. Indeed, this effect could have been further reduced by removing images taken under high zenith angles as was applied in this study.

469 The aforementioned factors may indeed have affected the stress patterns observed in this 470 study. We argue that such effects are random and cannot therefore generate a skewed 471 pattern which could be interpreted as a continuous NDVI decline. In reality, this type of 472 noise increases the variability in the data and potentially covers some less distinct stress 473 patterns, thus contributing to the portion of variability which could not have been 
474 explained by the regression models developed in this study. To address this issue in

475 greater detail, we conducted a supplementary investigation of the spectral response of

476 drying oak leaves using laboratory hemispheric spectroradiometer. In spite of limited

477 comparability of MODIS-based and laboratory-acquired spectral responses, our

478 experiment generated response which was highly consistent with that of MODIS (see

479 Appendix $\mathrm{C}$ for details). This finding supports our inferences and suggests that a

480 deviation from Lambertian assumption should not prevent the daily MODIS NDVI data

481 from being used in the research of diurnal vegetation dynamics.

482 High performance of tested regression models implies strong control of climatic variables

483 over the physiological response of beech and oak, leading to their potential use in

484 predicting drought stress from meteorological observations and improving

485 parameterisation of forest drought-stress indices. However, we identified a large number

486 of rainless periods of various duration, which did not induce an observable stress

487 response. Some are due to the inherent variability in tree response to moderate

488 environmental stress driven by the phenotypic plasticity (Valladares et al. 2007) and

489 environmental heterogeneity beyond the scale of observation. Others are generated by

490 missing or discarded NDVI observations due to pixel contamination or other reasons.

491 The use of rainless periods as indicators of drought stress in forest ecosystems has certain

492 limitations due to varying soils characteristics and landscape topography, which both

493 affect water availability to trees. In this study such effects were controlled for by

494 considering relief and soils in the initial plot selection, however caution must be exercised

495 when applying this methodology to a large or heterogeneous area. Precipitation measured

496 with rain gauges can be used as highly reliable input data, vegetation vigour was

497 repeatedly found very responsive to precipitation regime (e.g. Clifford et al. 2013; Plaut

498 et al. 2013). Although not feasible in this study, meteorological indicators of drought

499 should be verified and parameterised by direct measurements of soil water content for

500 best reliability of stress prediction. 
501 The forest area covered in this study extends to ca. $20,000 \mathrm{~km}^{2}$, however for the purpose

502 of this study we identified only 121 MODIS pixels $(250 \times 250 \mathrm{~m})$ which met the selection

503 criteria. The spatial resolution of MODIS data was a factor severely limiting the number

504 of suitable forest stands, chiefly due to our criterion of at least $99 \%$ cover of target

505 species in each MODIS pixel, but also due to limits on stand exposition, elevation and

506 soil type. Such strict selection, however, was applied for the purpose of inter-specific

507 comparison of stress responses and may not be necessary for different goals, such as

508 assessing stress status of large tracts of forests. The presented approach is suitable for tree

509 species with continuous cover, rather than for species with scattered distribution or for

510 open canopy situations.

\section{Conclusion}

513 Our analysis shows that MODIS-derived data describing intra-seasonal variation in NDVI

514 values can indicate periods of environmental stress in beech and oak forests. We show

515 that the incidence and magnitude of observed stress episodes can be explained by a set of

516 environmental variables describing temperature and precipitation patterns. Having

517 dissected the sensitivity of outlined methodology, we argue that MODIS data can be used

518 to infer and verify interactions between climate and forest vigour and productivity in

519 temperate broadleaf species with continuous distribution. In addition, a close examination

520 of stand-specific time series of MODIS-NDVI can provide ecophysiological data

521 complementary to terrestrial forest monitoring.

522 
523 Acknowledgements

524 This research is a result of the following projects: ITMS 26220120069 (35\%) and ITMS

52526220220066 (35\%); supported by the Operational Programme Research and

526 Development funded by the European Regional Development Fund; projects of the

527 Slovak Research and Development Agency under contracts APVV-0111-10 and APVV-

528 0022-07 (20\%), and project of the National Agency for Agriculture Research of the

529 Czech Republic QJ1220317 (10\%).

530 
532 Allen CD, Macalady AK, Chenchouni H, Bachelet D, McDowell N, Vennetier M,

533 Kitzberger T, Rigling A, Breshears DD, Hogg EH, Gonzalez P, Fensham R, Zhang Z,

534 Castro J, Demidova N, Lim J-H, Allard G, Running SW, Semerci A, Cobb N (2010) A

535 global overview of drought and heat-induced tree mortality reveals emerging climate

536 change risks for forests. For Ecol Manage 259:660-684.

537 Bréda N, Huc R, Granier A, Dreyer E (2006) Temperate forest trees and stands under

538 severe drought: a review of ecophysiological responses, adaptation processes and long-

539 term consequences. Ann For Sci 63:625-64.

540 Bruce LM, Mathur A, Byrd JD Jr. (2006) Denoising and Wavelet-Based Feature

541 Extraction of MODIS Multi-Temporal Vegetation Signatures. GIScience \& Remote

$542 \quad$ Sensing 43:67-77.

543 Caccamo G, Chisholm LA, Bradstock RA, Puotinen ML (2011) Assessing the sensitivity

544 of MODIS to monitor drought in high biomass ecosystems. Remote Sens Environ

$545 \quad 115: 2626-2639$.

546 Ceccato P, Flasse S, Tarantola S, Jacquemoud S, Grégoire JM (2001) Detecting

547 vegetation leaf water content using reflectance in the optical domain. Remote Sens

548 Environ 77:22-33.

549 Cheney P, Sullivan A (1997) Grassfires fuel, weather and fire behaviour. CSIRO

550 Publishing, Collingwood

551 Clifford MJ, Royer PD, Cobb NS, Breshears DD, Ford PL (2013) Precipitation

552 Thresholds and Drought-Induced Tree Die-off: Insights from Patterns of Pinus Edulis

553 Mortality along an Environmental Stress Gradient. New Phytol 200: 413-421.

554 Cochard H, Lemoine D, Dreyer E (1999) The effects of acclimation to sunlight on the

555 xylem vulnerability to embolism in Fagus sylvatica L. Plant Cell Environ 22: 101-108. 
556 Czúcz B, Gálhidy L, Mátyás C (2011) Present and forecasted xeric climatic limits of

557 beech and sessile oak distribution at low altitudes in Central Europe. Ann For Sci 68:99-

558108.

559 Engelbrecht BMJ, Kursar TA, Tyree MT (2005) Drought effects on seedling survival in a 560 tropical moist forest. Trees - Struct Funct 19: 312-321.

561 Epron D, Dreyer E (1993) Long-term effects of drought on photosynthesis of adult oak

562 trees [Quercus petraea (Matt.) Liebl. and Quercus robur L.] in a natural stand. New

563 Phytol 125:381-389.

564 Franch B, Vermote EF, Sobrino JA, Fédèle E (2013) Analysis of Directional Effects on

565 Atmospheric Correction. Remote Sens Environ 128: 276-288.

566 Geßler A, Keitel C, Kreuzwieser J, Matyssek R, Seiler W, Rennenberg H (2007)

567 Potential risks for European beech (Fagus sylvatica L.) in a changing climate. Trees

$568 \quad 21: 1-11$.

569 Glenn EP, Huete AR, Nagler PL, Nelson SG (2008) Relationship between remotely-

570 sensed vegetation indices, canopy attributes, and plant physiological processes: What

571 vegetation indices can and cannot tell us about the landscape. Sensors 8:2136-2160.

572 Hlásny T, Barcza Z, Fabrika M, Balázs B, Churkina G, Pajtík J, Sedmák R, Turčáni M

573 (2011a) Climate change impacts on growth and carbon balance of forests in Central

574 Europe. Clim Res 47:219-236.

575 Hlásny T, Kř́istek Š, Holuša J, Trombik J, Urbaňcová N (2011b) Snow disturbances in

576 secondary Norway spruce forests in Central Europe: Regression modeling and its

577 implications for forest management. For Ecol Manage 262:2151-2161.

578 Hmimina G, Dufrêne E, Pontailler J.-Y, Delpierre N, Aubinet M, Caquet B, de Grancourt

579 A, Burban B, Flechard C, Granier A, Gross P, Heinesch B, Longdoz B, Moureaux C,

580 Ourcival J-M, Rambal S, Saint André L, Soudani K (2013) Evaluation of the Potential of 
MODIS Satellite Data to Predict Vegetation Phenology in Different Biomes: An

582 Investigation Using Ground-Based NDVI Measurements. Remote Sens Environ 132:

$583 \quad 145-158$.

584 Ji L, Peters AJ (2003) Assessing vegetation response to drought in the northern Great

585 Plains using vegetation and drought indices. Remote Sens Environ 87:85-98.

586 Kotarba AZ (2009) A comparison of MODIS-derived cloud amount with visual surface

587 observations. Atmos Res 92: 522-530.

588 Lakatos F, Molnár M (2009) Mass mortality of beech in South-West Hungary. Acta

589 Silvatica \& Lignaria Hungarica, 5: 75 - 82.

590 Le Dantec V, Dufrêne E, Saugier B (2000) Interannual and spatial variation in maximum

591 leaf area index of temperate deciduous stands. For Ecol Manage 134:71-81.

592 Leuschner C, Backes K, Hertel D, Schipka F, Schmitt U, Terborg O, Runge M (2001)

593 Drought responses at leaf, stem and fine root levels of competitive Fagus sylvatica L. and

594 Quercus petraea (Matt.) Liebl. trees in dry and wet years. For Ecol Manage 149:33-46.

595 Leuzinger, S, Zotz G, Asshoff R, Körner C (2005) Responses of deciduous forest trees to

596 severe drought in Central Europe. Tree Physiol 25:641-650.

597 Lobo A, Maisongrande P, Coret L (2010) The impact of the heat wave of summer 2003 in

598 SW Europe as observed from satellite imagery. Phys Chem Earth, Parts A/B/C 35:19-24.

599 Mátyás C, Berki I, Czúcz B, Gálos B, Móricz N, Rasztovits E (2010) Future of Beech in

600 Southeast Europe from the Perspective of Evolutionary Ecology. Acta Silv Lign Hung

$601 \quad 6: 91-110$.

602 McDowell N, Pockman WT, Allen CD, Breshears DD, Cobb N, Kolb T, Plaut J, Sperry J,

603 West A, Williams DG, Yepez EA (2008) Mechanisms of plant survival and mortality

604 during drought: Why do some plants survive while others succumb to drought? New

605 Phytol 178:719-739. 
607 Sens Environ 49:200-211.

608 Nahm M, Matzarakis A, Rennenberg H, Geßler A (2007) Seasonal courses of key

609 parameters of nitrogen, carbon and water balance in European beech (Fagus sylvatica L.)

610 grown on four different study sites along a European North-South climate gradient

611 during the 2003 drought. Trees 21:79-92.

612 Polle A, Schwanz P, Rudolf C (2001) Developmental and seasonal changes of stress

613 responsiveness in beech leaves (Fagus sylvatica L.). Plant Cell Environ 24:821-829.

614 Plaut J, Wadsworth WD, Pangle R, Yepez EA, McDowell NG, Pockman WT (2013)

615 Reduced Transpiration Response to Precipitation Pulses Precedes Mortality in a Piñon-

616 Juniper Woodland Subject to Prolonged Drought. New Phytol 200: 375-387.

617 Raftoyannis Y, Radoglou K (2002) Physiological responses of beech and sessile oak in a

618 natural mixed stand during a dry summer. Ann Bot 89:723-730.

619 Renaud JP, Nageleisen LM (2005) Results from the European Network For Damage

620 Monitoring. Bilan de la santé des forêts en 2004, 2005, Département de la santé des

621 forêts, Paris.

622 Rennenberg H, Loreto F, Polle A, Brilli F, Fares S, Beniwal RS, Gessler A (2006)

623 Physiological Responses of Forest Trees to Heat and Drought. Plant Biology 8:556-571.

624 Rouault, G., J.N. Candau, F. Lieutier, L.M. Nageleisen, J.C. Martin, and N. Varzée. 2006.

625 Effects of drought and heat on forest insect populations in relation to the 2003 drought in

626 Western Europe. Ann For Sci 63:613-624.

627 Sack L 2004. Responses of temperate woody seedlings to shade and drought: Do trade-

628 offs limit potential niche differentiation? Oikos 107: 110-127. 
629 Scharnweber T, Manthey M, Criegee C, Bauwe A, Schröder C, Wilmking M (2011)

630 Drought matters - Declining precipitation influences growth of Fagus sylvatica L. and

631 Quercus robur L. in north-eastern Germany. For Ecol Manage 262:947-961.

632 Shuai et al. 2013

633 Soudani K, Hmimina G, Delpierre N, Pontailler J-Y, Aubinet M, Bonal D, Caquet B, de 634 Grandcourt A, Burban B, Flechard C, Guyon D, Granier A, Gross P, Heinesh B, Longdoz

635 B, Loustau D, Moureaux C,Ourcival J-M, Rambal S, Saint André L, Dufrêne E (2012)

636 Ground-based Network of NDVI measurements for tracking temporal dynamics of 637 canopy structure and vegetation phenology in different biomes. Remote Sens Environ $638 \quad 123: 234-245$.

639 Thomsen JE, Bohrer G, Matheny AM, Ivanov VY, He L, Renninger HJ, Schäfer KVR 640 (2013) Contrasting Hydraulic Strategies during Dry Soil Conditions in Quercus rubra 641 and Acer rubrum in a Sandy Site in Michigan. Forests 4, 1106-1120.

642 Vacchiano, G., M. Garbarino, E.B. Mondino, and R. Motta. 2012. Evidences of drought 643 stress as a predisposing factor to Scots pinedecline in Valle d'Aosta (Italy). Eur J For Res 644 131:989-1000.

645 Valladares F, Gianoli E, Gómez JM (2007) Ecological limits to plant phenotypic 646 plasticity. New Phytol 176:749-63.

647 van der Salm C, Reinds GJ, de Vries W (2007) Water balances in intensively monitored 648 forest ecosystems in Europe. Environ Pollut 148:201-212.

649 Vicente-Serrano SM, Beguería S, Lorenzo-Lacruz J, Camarero JJ, López-Moreno JI, 650 Azorin-Molina C, Revuelto J, Morán-Tejeda E, Sanchez-Lorenzo A (2012) Performance 651 of Drought Indices for Ecological, Agricultural, and Hydrological Applications. Earth 652 Interact 16:1-27. 
653 Wamelink GWW, Wieggers HJJ, Reinds GJ, Kros J, Mol-Dijkstra JP, van Oijen M, de 654 Vries W (2009) Modelling impacts of changes in carbon dioxide concentration, climate 655 and nitrogen deposition on carbon sequestration by European forests and forest soils. For 656 Ecol Manage 258:1794-1805.

657 Wang J, Rich PM, Price KP (2003) Temporal responses of NDVI to precipitation and 658 temperature in the central Great Plains, USA. Int J Remote Sens 24:2345-2364.

659 Wang LL, Qu JJ, Xiong XX, Hao XJ (2009) Analysis of seven-year moderate resolution 660 imaging spectroradiometer vegetation water indices for drought and fire activity 661 assessment over Georgia of the United States. J Appl Remote Sens 3:033555.

662 Weber P, Bugmann H, Pluess AR, Walthert L, Rigling A (2012) Drought response and 663 changing mean sensitivity of European beech close to the dry distribution limit. Trees $66427: 171-181$.

665

666 
667 Table 1 Criteria for the selection of forest stands used for the assessment of heat and 668 drought effect on beech and oak stands

669

670

\begin{tabular}{ll}
\hline Criterion & Limits \\
\hline Percentage of investigated species & $>99 \%$ \\
Altitude & $<670 \mathrm{~m}$ a.s.l. for oak; $<850 \mathrm{~m}$ a.s.l. for beech \\
Relief aspect & southern slopes \\
Stand age & $>50$ years \\
& $<15 \mathrm{~km}$ from station with air temperature data; \\
Distance from meteorological station & $<7$ km from station with precipitation data \\
Vertical structure of stands & Single-storey stands only \\
Soil and bedrock & Homogenous across the pixels within group
\end{tabular}

671

672

673

674

675 
676 Table 2 Descriptive data of beech and oak forest stands covered by the clusters of 677 MODIS pixels used in the investigation NDVI response to drought and heat stress. Mean 678 values and standard deviations are given.

\begin{tabular}{|c|c|c|c|c|c|c|c|c|c|c|c|}
\hline- & EP & NoP & Altitude & Slope & Aspect & Age & Density & DifAltT & DifAltP & DifT & DifP \\
\hline \multirow{14}{*}{ 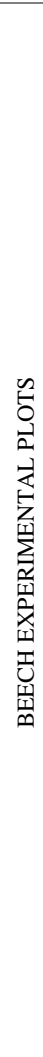 } & & & [m a.s.l.] & [\%] & {$\left[{ }^{\circ}\right]$} & [years] & {$[-]$} & [m a.s.l.] & [m a.s.l.] & {$[\mathrm{m}]$} & {$[\mathrm{m}]$} \\
\hline & 1 & 6 & $479 \pm 26$ & $13 \pm 3.8$ & $235 \pm 8$ & $62 \pm 13$ & $0.9 \pm 0.1$ & 484 & 226 & 5,247 & 2,681 \\
\hline & 2 & 4 & $515 \pm 25$ & $16 \pm 2.8$ & $189 \pm 18$ & $97 \pm 41$ & $0.8 \pm 0.1$ & 533 & 533 & 5,182 & 5,186 \\
\hline & 3 & 4 & $526 \pm 17$ & $9 \pm 1.3$ & $159 \pm 28$ & $95 \pm 18$ & $0.8 \pm 0.1$ & 533 & 533 & 4,397 & 4,401 \\
\hline & 4 & 5 & $433 \pm 34$ & $10 \pm 2.7$ & $148 \pm 32$ & $113 \pm 7$ & $0.8 \pm 0.1$ & 533 & 225 & 11,812 & 5,625 \\
\hline & 5 & 4 & $655 \pm 72$ & $29 \pm 2.6$ & $150 \pm 36$ & $121 \pm 9$ & $0.6 \pm 0.1$ & 254 & 315 & 9,177 & 3,331 \\
\hline & 6 & 4 & $688 \pm 63$ & $31 \pm 3.2$ & $192 \pm 38$ & $139 \pm 3$ & $0.7 \pm 0.0$ & 254 & 650 & 11,047 & 2,585 \\
\hline & 7 & 7 & $714 \pm 68$ & $29 \pm 1.8$ & $174 \pm 62$ & $103 \pm 6$ & $0.8 \pm 0.0$ & 411 & 502 & 7,902 & 3,283 \\
\hline & 8 & 5 & $742 \pm 106$ & $26 \pm 4.3$ & $138 \pm 19$ & $114 \pm 7$ & $0.7 \pm 0.0$ & 875 & 583 & 5,535 & 4,620 \\
\hline & 9 & 4 & $686 \pm 22$ & $11 \pm 1.2$ & $237 \pm 8$ & $88 \pm 6$ & $0.8 \pm 0.1$ & 140 & 397 & 14,481 & 2,906 \\
\hline & 10 & 10 & $491 \pm 26$ & $13 \pm 1.8$ & $212 \pm 27$ & $97 \pm 10$ & $0.7 \pm 0.1$ & 305 & 287 & 5,792 & 5,263 \\
\hline & 11 & 4 & $443 \pm 31$ & $16 \pm 1.6$ & $239 \pm 14$ & $92 \pm 5$ & $0.7 \pm 0.0$ & 305 & 262 & 6,216 & 3,305 \\
\hline & 12 & 2 & $398 \pm 21$ & $17 \pm 1.5$ & $126 \pm 13$ & $100 \pm 0$ & $0.7 \pm 0.0$ & 305 & 232 & 16,275 & 6,633 \\
\hline & 13 & 7 & $505 \pm 24$ & $14 \pm 1.3$ & $196 \pm 55$ & $78 \pm 6$ & $0.8 \pm 0.0$ & 122 & 338 & 12,631 & 2,566 \\
\hline \multirow{8}{*}{ 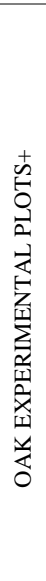 } & 1 & 10 & $397 \pm 31$ & $11 \pm 2.6$ & $170 \pm 16$ & $93 \pm 13$ & $0.8 \pm 0.1$ & 180 & 315 & 13,564 & 4,806 \\
\hline & 2 & 5 & $410 \pm 28$ & $13 \pm 2.0$ & $225 \pm 0$ & $98 \pm 13$ & $0.7 \pm 0.1$ & 318 & 191 & 10,406 & 5,066 \\
\hline & 3 & 4 & $544 \pm 8$ & $6 \pm 3.6$ & $201 \pm 36$ & $54 \pm 2$ & $0.9 \pm 0.1$ & 139 & 241 & 13,290 & 5,987 \\
\hline & 4 & 10 & $574 \pm 57$ & $15 \pm 2.4$ & $176 \pm 41$ & $83 \pm 17$ & $0.7 \pm 0.0$ & 318 & 338 & 2,676 & 2,241 \\
\hline & 5 & 7 & $186 \pm 7$ & $2 \pm 0.4$ & $141 \pm 16$ & $71 \pm 13$ & $0.7 \pm 0.0$ & 110 & 117 & 8,550 & 6,878 \\
\hline & 6 & 6 & $376 \pm 24$ & $8 \pm 1.8$ & $176 \pm 63$ & $85 \pm 1$ & $0.8 \pm 0.0$ & 100 & 160 & 9,005 & 2,923 \\
\hline & 7 & 6 & $295 \pm 22$ & $11 \pm 1.2$ & $78 \pm 23$ & $75 \pm 15$ & $0.8 \pm 0.0$ & 100 & 160 & 7,475 & 3,925 \\
\hline & 8 & 7 & $174 \pm 4$ & $3 \pm 1.7$ & $92 \pm 107$ & $67 \pm 9$ & $0.7 \pm 0.0$ & 100 & 100 & 7,116 & 1,916 \\
\hline
\end{tabular}

Abbreviations: EP - Experimental Plot; NoP - Number of MODIS Pixels covering an EP; Slope - mean relief slope within an EP; Aspect - mean relief aspect within an EP; Density - mean stand density within an EP; DiffAltT - mean altitudinal difference between an EP and meteorological stations used for the air temperature interpolation; DifAltP - altitudinal difference between an EP and the meteorological station used for the calculation of rainless periods; DiftT - mean horizontal distance between an EP and meteorological stations used for the calculation of air temperature-related extremes; DifP 
685 Table 3 Descriptive statistics of maximum observed NDVI declines, described in terms 686 of percentage decline from the total NDVI amplitude, that occurred as a result of potential 687 drought and heat stress during the period 2000-2010 in oak and beech stands in Central 688 Europe. The variable describes the maximum stress induced by climatic factors to beech 689 and oak that was recorded using MODIS imagery.

\begin{tabular}{ccccccccc}
\hline & $\mathrm{N}$ & Mean & Med & Min & Max & 0.25 & 0.75 & StDev \\
\hline Beech & 166.00 & 10.59 & 8.88 & 5.00 & 27.55 & 6.59 & 12.74 & 691 \\
Oak & 173.00 & 12.47 & 9.71 & 5.00 & 41.81 & 6.86 & 14.53 & $\begin{array}{r}8.70 \\
692\end{array}$ \\
\hline
\end{tabular}

693 
694 Table 4 Descriptive statistics of explanatory variables used in the regression modelling of

695 drought and heat effects on the variation in MODIS NDVI in oak and beech stands in

696 Central Europe

697

\begin{tabular}{|c|c|c|c|c|c|c|c|c|c|c|c|c|}
\hline \multirow[b]{2}{*}{ Variables } & \multicolumn{6}{|c|}{ BEECH EXPERIMENTAL PLOTS } & \multicolumn{6}{|c|}{ OAK EXPERIMENTAL PLOTS } \\
\hline & $\mathrm{N}$ & Mean & Med & Min & Max & StDev & $\mathrm{N}$ & Mean & Med & Min & $\operatorname{Max}$ & StDev \\
\hline GDD & 167 & 767 & 703 & 349 & 1443 & 332 & 173 & 917 & 954 & 334 & 1410 & 334 \\
\hline Tavg & 167 & 19.37 & 18.90 & 13.50 & 24.20 & 2.56 & 173 & 19.39 & 19.30 & 15.90 & 23.20 & 1.84 \\
\hline $\operatorname{Tmax}$ & 167 & 31.57 & 32.10 & 27.40 & 35.20 & 2.33 & 173 & 31.35 & 31.70 & 26.60 & 35.00 & 2.24 \\
\hline Tmin & 167 & 8.25 & 8.60 & -0.50 & 15.90 & 4.55 & 173 & 8.43 & 8.60 & 3.60 & 13.10 & 2.71 \\
\hline N-Tavg $>15^{\circ} \mathrm{C}$ & 167 & 10.59 & 9.00 & 4.00 & 27.00 & 4.97 & 173 & 12.31 & 11.00 & 4.00 & 42.00 & 5.57 \\
\hline N-Tavg $>18^{\circ} \mathrm{C}$ & 167 & 8.10 & 7.00 & 2.00 & 18.00 & 4.02 & 173 & 9.52 & 9.00 & 2.00 & 32.00 & 4.93 \\
\hline N-Tavg $>21^{\circ} \mathrm{C}$ & 167 & 4.62 & 5.00 & 0.00 & 13.00 & 3.93 & 173 & 4.62 & 4.00 & 0.00 & 14.00 & 2.94 \\
\hline N-Tavg $>24^{\circ} \mathrm{C}$ & 167 & 1.80 & 1.00 & 0.00 & 6.00 & 2.10 & 173 & 1.24 & 1.00 & 0.00 & 8.00 & 1.53 \\
\hline N-Tavg $>27^{\circ} \mathrm{C}$ & 167 & 0.08 & 0.00 & 0.00 & 1.00 & 0.28 & 173 & 0.00 & 0.00 & 0.00 & 0.00 & 0.00 \\
\hline $\mathrm{N}-\mathrm{Tmax}>20^{\circ} \mathrm{C}$ & 167 & 11.49 & 10.00 & 5.00 & 29.00 & 5.24 & 173 & 12.98 & 11.00 & 5.00 & 42.00 & 5.30 \\
\hline $\mathrm{N}-\mathrm{T} \max >23^{\circ} \mathrm{C}$ & 167 & 9.41 & 8.00 & 4.00 & 22.00 & 3.97 & 173 & 11.29 & 10.00 & 4.00 & 38.00 & 5.16 \\
\hline $\mathrm{N}-\mathrm{Tmax}>26^{\circ} \mathrm{C}$ & 167 & 7.32 & 7.00 & 3.00 & 13.00 & 2.97 & 173 & 7.55 & 7.00 & 1.00 & 26.00 & 3.88 \\
\hline $\mathrm{N}-\mathrm{Tmax}>29^{\circ} \mathrm{C}$ & 167 & 3.96 & 5.00 & 0.00 & 10.00 & 3.08 & 173 & 3.76 & 4.00 & 0.00 & 12.00 & 2.98 \\
\hline $\mathrm{N}-\mathrm{Tmax}>32^{\circ} \mathrm{C}$ & 167 & 1.19 & 1.00 & 0.00 & 4.00 & 1.43 & 173 & 1.04 & 0.00 & 0.00 & 6.00 & 1.48 \\
\hline $\mathrm{N}-\mathrm{T} \max >35^{\circ} \mathrm{C}$ & 167 & 0.06 & 0.00 & 0.00 & 1.00 & 0.24 & 173 & 0.00 & 0.00 & 0.00 & 0.00 & 0.00 \\
\hline Drt & 166 & 13 & 10.00 & 5.00 & 27.00 & 5.99 & 173 & 13 & 12.00 & 5.00 & 24.00 & 5.19 \\
\hline Age & 167 & 89 & 91 & 50 & 135 & 17 & 173 & 77 & 81 & 50 & 112 & 12 \\
\hline Elev & 167 & 531 & 500 & 391 & 845 & 105 & 173 & 341 & 320 & 166 & 661 & 134 \\
\hline
\end{tabular}

698

Abbreviations: GDD - growing degree days; Drt - length of drought period; Age - mean stand age; Elev - mean stand elevation; Tavg - mean air

temperature during a drought period; Tmax - maximum air temperature during a drought period; Tmin - minimum air temperature during a drought

period; N-Tavg $>18^{\circ} \mathrm{C}$ (or $>21^{\circ} \mathrm{C},>24^{\circ} \mathrm{C},>27^{\circ} \mathrm{C}$ ) - number of days with mean air temperature above $18^{\circ} \mathrm{C}$ (or above $21^{\circ} \mathrm{C}, 24^{\circ} \mathrm{C}, 27^{\circ} \mathrm{C}$ ), which

occurred during a stress episode; N-Tmax $>20^{\circ} \mathrm{C}$ (or $>23^{\circ} \mathrm{C},>26^{\circ} \mathrm{C},>29^{\circ} \mathrm{C},>32^{\circ} \mathrm{C},>35^{\circ} \mathrm{C}$ ) - number of days with maximum air temperature above

702

$20^{\circ} \mathrm{C}$ (or above $23^{\circ} \mathrm{C}, 26^{\circ} \mathrm{C}, 29^{\circ} \mathrm{C}, 32^{\circ} \mathrm{C}, 35^{\circ} \mathrm{C}$ ), which occurred during a stress episode 
708 Table 5 Mean Pearson's correlation coefficients between Neural Networks predicted and 709 observed decline in NDVI value of beech and oak stands calculated for training, testing

710 and validation sets. These coefficients are calculated from a set of the best performing

711 Neural Networks. Correlation coefficients indicate the overall performance of neural

712 network-based regression models

713

\begin{tabular}{llll}
\hline & Training & Testing & Validation \\
\hline Beech & $0.86 \pm 6 \%$ & $0.82 \pm 8 \%$ & $0.93 \pm 0.6 \%$ \\
Oak & $0.88 \pm 1.0 \%$ & $0.81 \pm 9 \%$ & $0.96 \pm 0.3 \%$ \\
\hline
\end{tabular}

714 
Table 6 Mean sensitivity scores of explanatory variables produced by 15 best-performing Neural Networks. The scores indicate the predictive power of

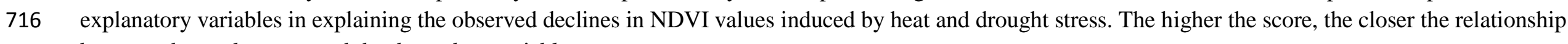
717 between the explanatory and the dependent variables.

\begin{tabular}{|c|c|c|c|c|c|c|c|c|c|c|c|c|c|c|c|c|c|}
\hline \multicolumn{18}{|c|}{ BEECH EXPERIMENTAL PLOTS } \\
\hline GDD & $\begin{array}{c}\text { N-Tmax } \\
>29^{\circ} \mathrm{C}\end{array}$ & $\begin{array}{c}\text { N-Tmax } \\
>20^{\circ} \mathrm{C}\end{array}$ & Tmax & $\begin{array}{c}\text { N-Tavg } \\
>24^{\circ} \mathrm{C}\end{array}$ & $\begin{array}{c}\text { N-Tavg } \\
>18^{\circ} \mathrm{C}\end{array}$ & Tmin & $\begin{array}{c}\text { N-Tmax } \\
>32^{\circ} \mathrm{C}\end{array}$ & $\begin{array}{l}\text { N-Tavg } \\
>21^{\circ} \mathrm{C}\end{array}$ & $\begin{array}{c}\text { N-Tavg } \\
>15^{\circ} \mathrm{C}\end{array}$ & Tavg & Age & $\begin{array}{c}\text { N-Tmax } \\
>26^{\circ} \mathrm{C}\end{array}$ & $\begin{array}{c}\text { N-Tmax } \\
>23^{\circ} \mathrm{C}\end{array}$ & Drt & Elev & Slope & Aspect \\
\hline 4.62 & 4.00 & 3.90 & 3.31 & 3.29 & 2.68 & 2.51 & 2.42 & 2.34 & 2.31 & 1.50 & 1.50 & 1.43 & 1.28 & 1.27 & 1.19 & 1.13 & 1.04 \\
\hline \multicolumn{18}{|c|}{ OAK EXPERIMENTAL PLOTS } \\
\hline $\begin{array}{c}\text { N-Tavg } \\
>24^{\circ} \mathrm{C}\end{array}$ & $\begin{array}{c}\text { N-Tmax } \\
>32^{\circ} \mathrm{C}\end{array}$ & $\begin{array}{c}\text { N-Tmax } \\
>29^{\circ} \mathrm{C}\end{array}$ & $\begin{array}{l}\text { N-Tavg } \\
>21^{\circ} \mathrm{C}\end{array}$ & GDD & $\begin{array}{c}\text { N-Tmax } \\
>20^{\circ} \mathrm{C}\end{array}$ & Tmax & $\begin{array}{c}\text { N-Tavg } \\
>15^{\circ} \mathrm{C}\end{array}$ & Tavg & Age & Tmin & Drt & Elev & $\begin{array}{c}\text { N-Tavg } \\
>18^{\circ} \mathrm{C}\end{array}$ & $\begin{array}{c}\text { N-Tmax } \\
>26^{\circ} \mathrm{C}\end{array}$ & Aspect & Slope & $\begin{array}{l}\mathrm{N}-\mathrm{T} \max \\
>23^{\circ} \mathrm{C}\end{array}$ \\
\hline 5.60 & 3.18 & 2.51 & 1.63 & 1.61 & 1.54 & 1.54 & 1.53 & 1.48 & 1.42 & 1.38 & 1.32 & 1.29 & 1.28 & 1.24 & 1.23 & 1.18 & 1.17 \\
\hline
\end{tabular}

Abbreviations: GDD - growing degree days; Drt - length of drought period; Age - mean stand age; Elev - mean stand elevation; Tavg - mean air temperature during a drought period; Tmax - maximum air temperature during a drought period; Tmin - minimum air 
725 Fig. 1 Position of the clusters of MODIS pixels covering homogenous mature beech and oak stands used for the investigations of MODIS-NDVI response to drought and heat stress. Meteorological stations used for the interpolation of climate data to the position of analysed groups of pixels are also shown.

Fig. 2 Seasonal course of MODIS-NDVI observations from a single stand in one year (dots). Arrow identifies a typical episode of NDVI decline symptomatic of climatic stress. $\mathrm{NDVI}_{\max }$ represents the mean of 2-4 NDVI observation immediately preceding a stress episode (local maximum), $\mathrm{NDVI}_{\text {stress }}$ is the value at the end of a stress episode, and $\mathrm{NDVI}_{\min }$ is the lowest NDVI value observed in local conditions.

735

Fig. 3 Univariate relationships between maximum NDVI declines and predictor variables which were identified as the most influential by neural networks-based regression modelling in oak stands.

Fig. 4 Univariate relationships between maximum NDVI declines and predictor variables which were identified as the most influential by neural networks-based regression modelling in beech stands.

741

742 Fig. 5 Frequency of rainless periods longer than 3 days which did (dark columns) and did not (hashed columns) induce an observable decline in NDVI 


\section{Appendix captions}

\section{Appendix A}

747 Example of experimental plots used for the investigation of MODIS-NDVI responses to climatic

748 stress. Each experimental plot in our experimental design consists of 4-13 MODIS pixels (250×250m)

749

$750 \quad$ Appendix B

751 An example of declining sequences of MODIS-NDVI identified in NDVI time series for selected

752 beech and oak dominated MODIS pixels for the period 2000-2010. Such sequences are indicative of

753 environmental stress affecting the physiological performance and spectral reflectance of vegetation.

754 
756 Reflectance of mature homogenous stands within two MODIS pixels with spatial resolution $250 \times 250$

757 meters in red and near infrared (VNIR) spectral bands is shown in panes A) and B). Pane A)

758

759

760

761

762

763

764

765

766

767

768

769

770

771

772

773 represents an 80 year old pure oak stand undergoing a rainless period lasting 18 days, while pane B) shows values from a pixel covering an 80 year old pure beech stand affected by a 12 day rainless period. Panes A1) and B1) show raw reflectance values, while A2) and B2) show percentage change relative to the reflectance measured on the day of the last rain event.

Spectral reflectance values in panes C) were measured by the LI-1800 Portable Spectroradiometer using 1800-12 Integration Sphere (Licor Inc.) collecting radiation reflected from the sampled material illuminated by a glass-halogen lamp. Three fresh overlapping leaves of Quercus robur were positioned in the sphere chamber without water and continuous reflectance readings were recorded for 54 hours with unequal time step in the range $400-1100 \mathrm{~nm}$. At the end of the observation, the leaves were dry beyond natural range found in the field conditions in Central Europe. This supplementary analysis shows that spectral change in leaves with limited water availability observed by the MODIS sensor at stand scale is very consistent with changes observed in laboratory conditions at the leaf scale. The latter is free of any atmospheric or weather related interferences. This indicates that, despite the limited comparability of the two sets of spectral responses, daily MODIS data can provide realistic information on vegetation stress dynamics which can be readily distinguished from intra-seasonal vegetation dynamics. 

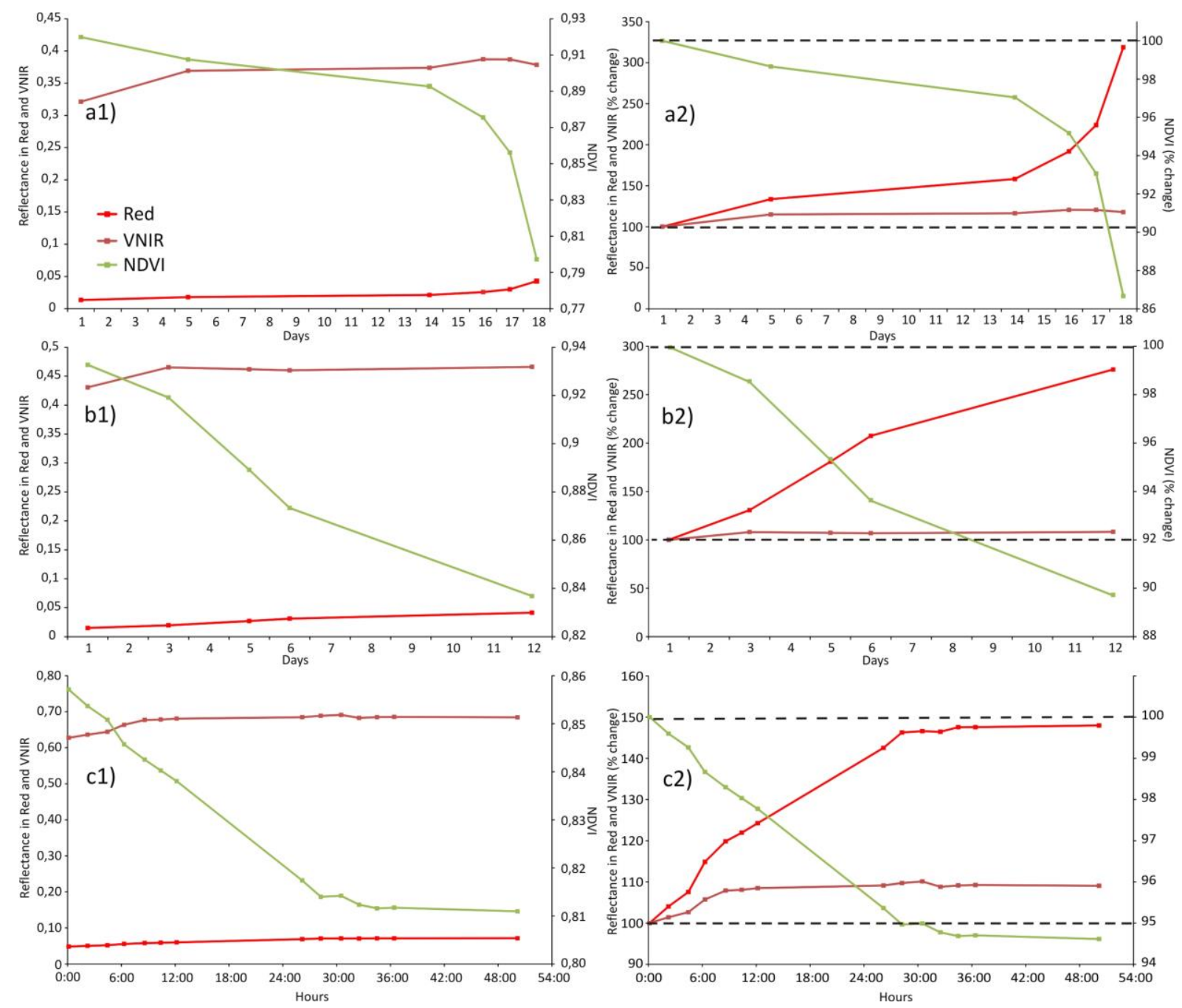
Figures

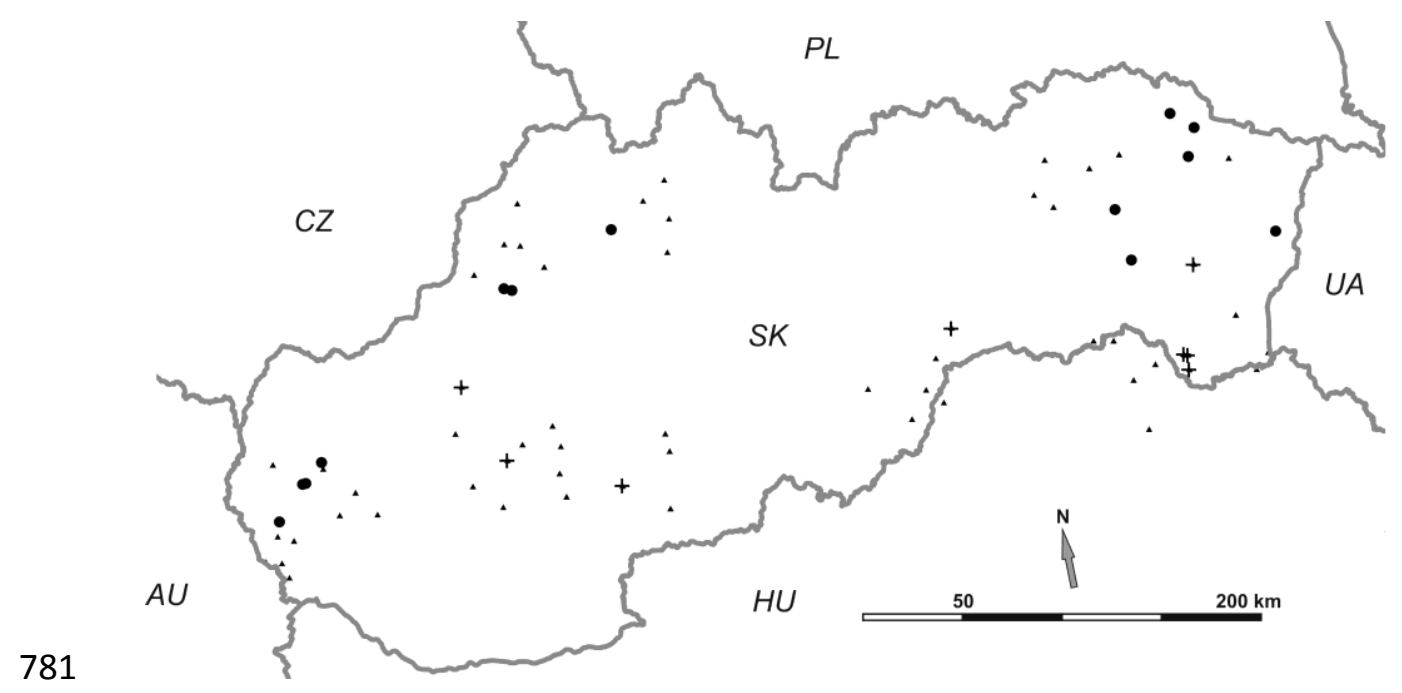

782 Fig. 1 


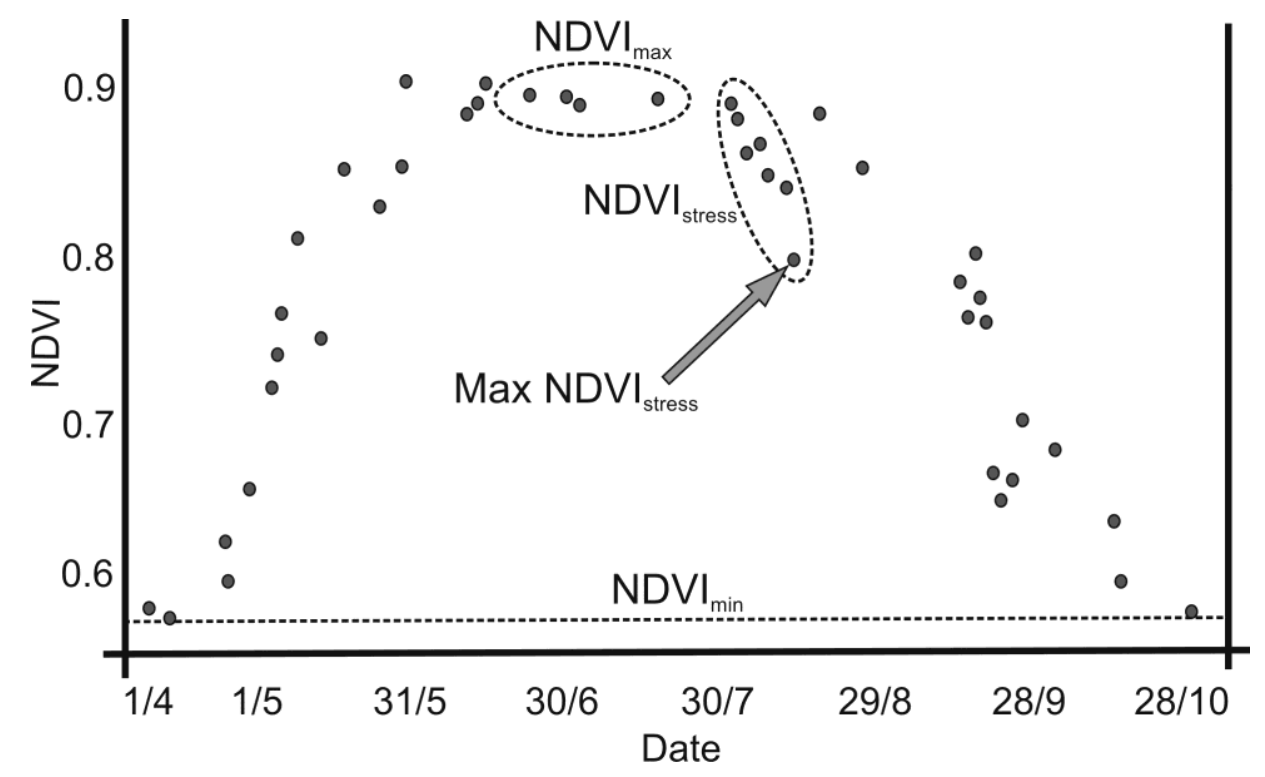

783

784 Fig. 2 

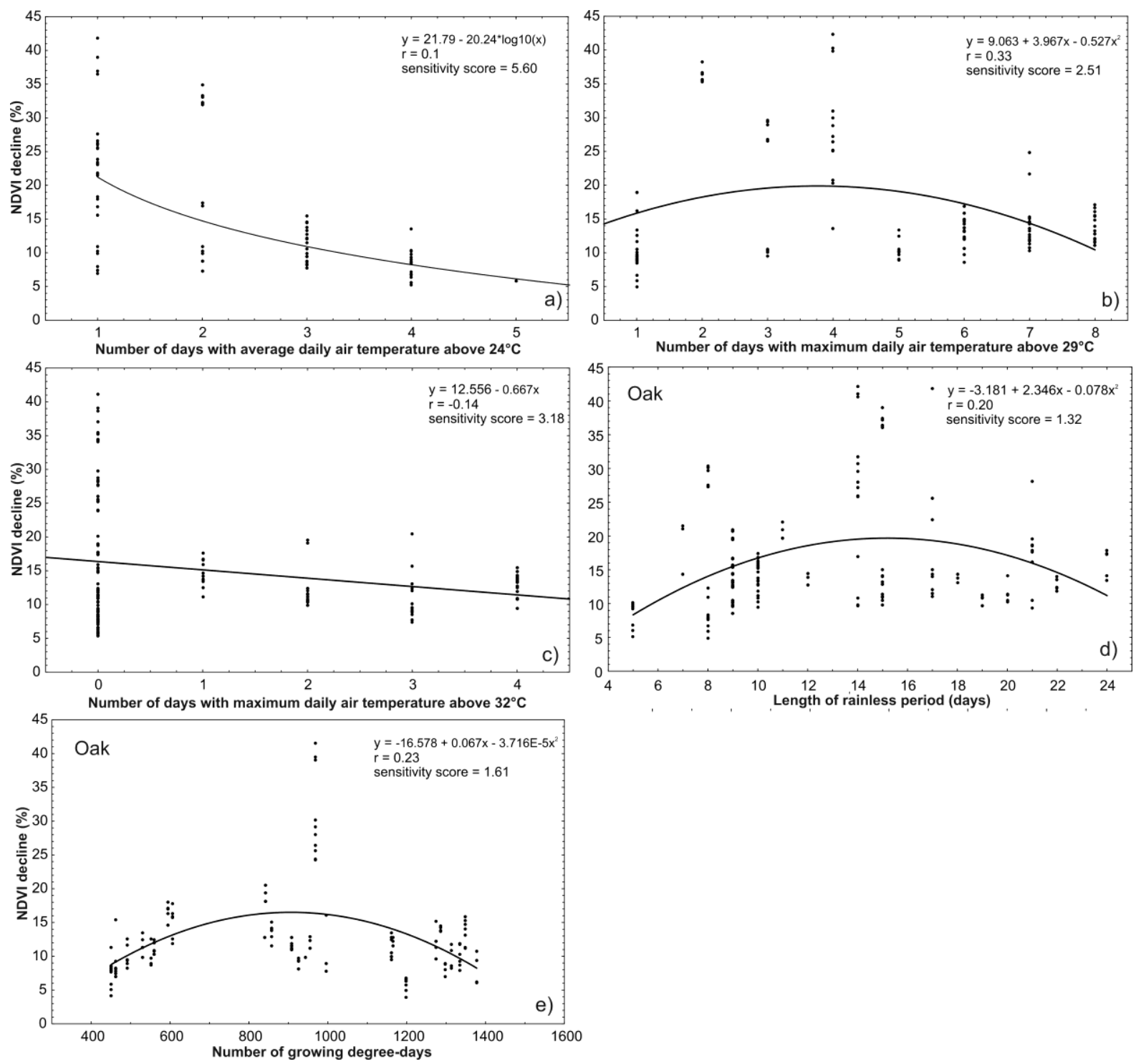

786

Fig. 3 

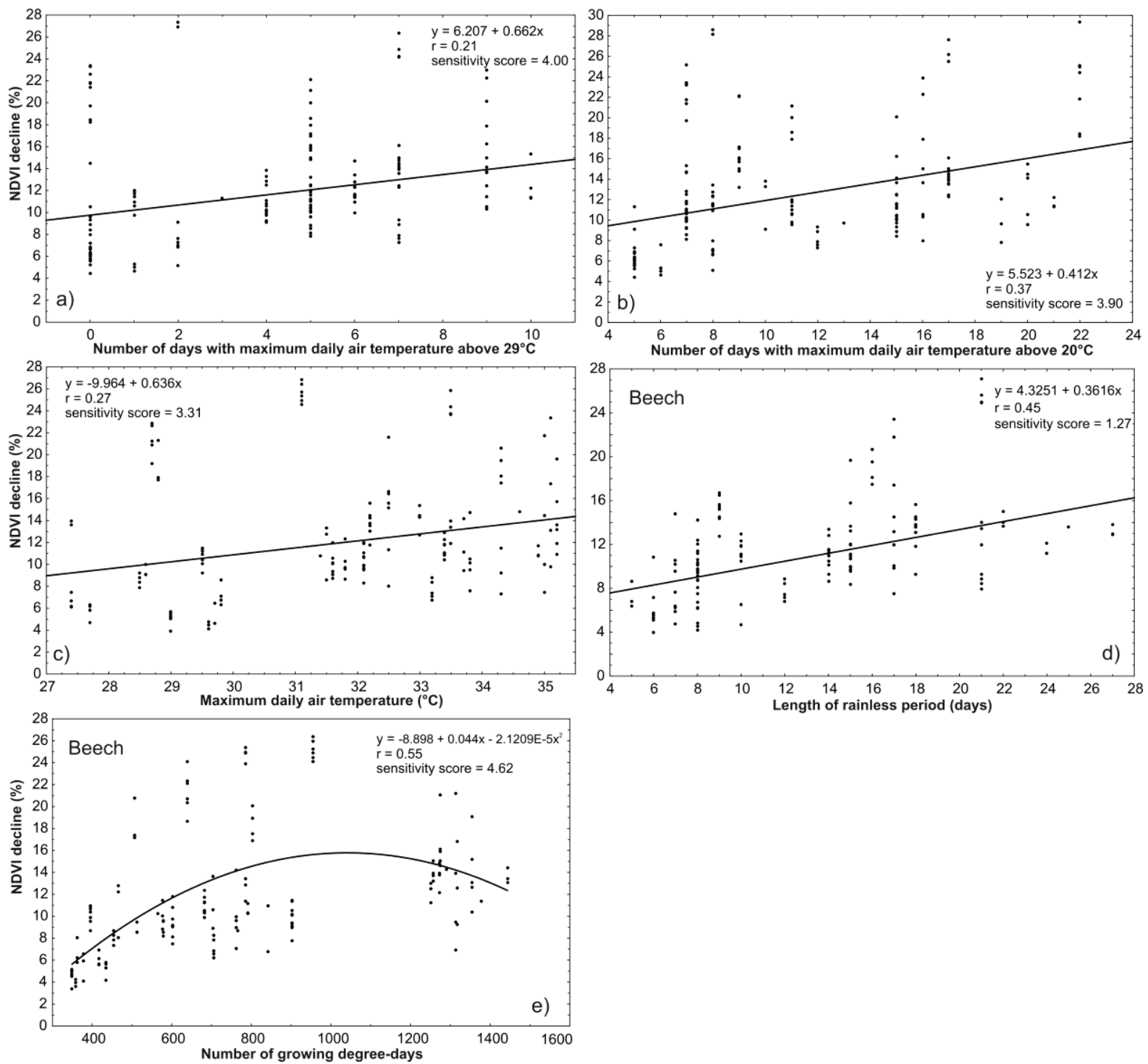

Fig. 4 


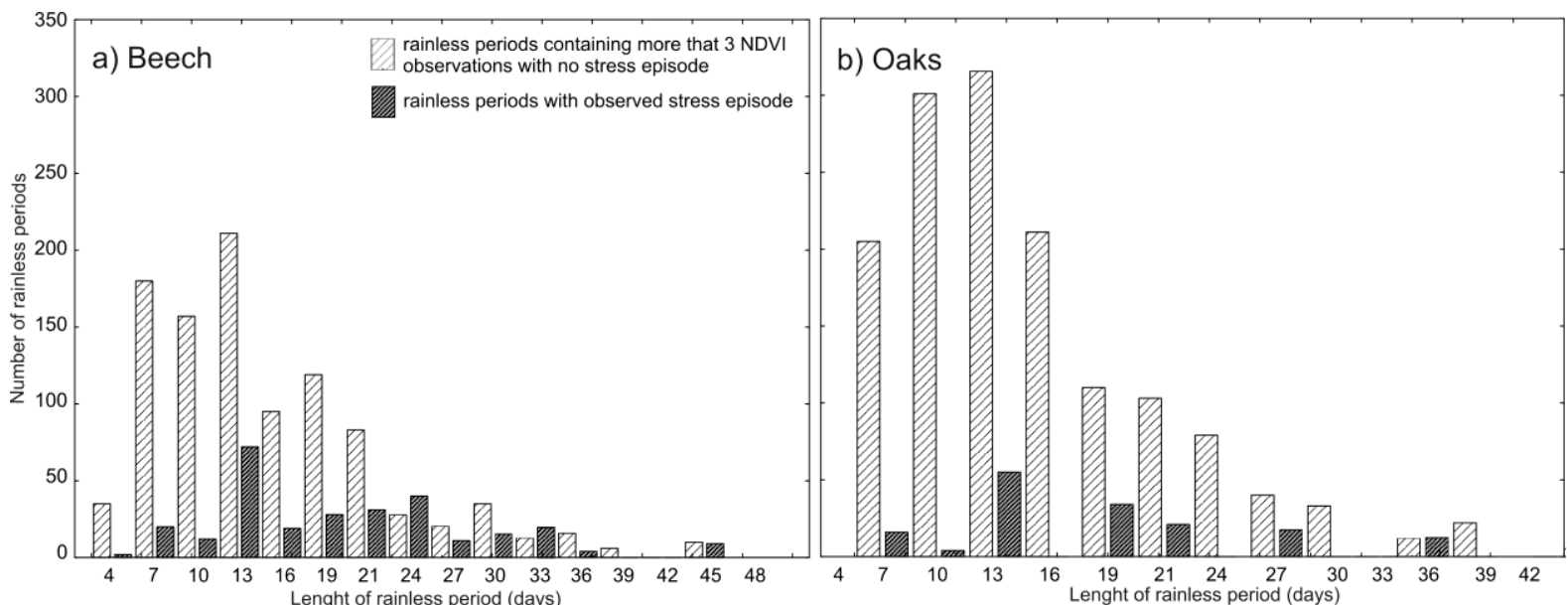

791

Fig. 5

792

793 